\title{
Is diatom richness responding to catchment glaciation? A case study from Canadian headwater streams
}

\author{
Doris GESIERICH*, and Eugen ROTT \\ Institute of Botany, University of Innsbruck, Sternwartestrasse 15, 6020 Innsbruck, Austria \\ *Corresponding author: doris.gesierich@uibk.ac.at
}

\begin{abstract}
Due to global change affecting glaciers worldwide, glacial streams are seen as threatened environments deserving specific scientific interest. Glacial streams from the Coast Range and Rocky Mountains in British Columbia and at the border to Alberta were investigated. In particular glacial streams and downstream sites in the Joffré Lakes Provincial Park, a near by mountain river and two large glacial streams in the Rocky Mountains (Kootenay Range, Jasper National Park) were studied. Regardless of a high variability of catchment glaciation (1 to 99\%) thin organic biofilms with firmly attached diatom frustules of the genera Achnanthidium, Psammothidium, Encyonema, Gomphonema and fragilaroid taxa were found in all cases. In spite of fundamentally different geological conditions between the Coast Range sites and the Rocky Mountain sites, the pioneer taxon Achnanthidium minutissimum (with a slimy long ecomorph) was dominating quantitatively in most of the glacier stream samples together with the rheobiontic Hannaea arcus. Individual glacier stream samples were characterized by the dominance of Achnanthidium petersenii and Gomphonema calcifugum/Encyonema latens. The diatom community analysis (cluster analysis) revealed the expected separation of glacier stream sites and sites of the lower segments of the river continuum (e.g., dominance of Diatoma ehrenbergii in the mountain river). In the Joffré area, the total species richness of turbid glacial streams close to the glacier mouth was significantly lower than in the more distant sites. The two largest glacial streams in the Rocky Mountains showed divergent results with a remarkable high species richness (43 taxa) at the Athabasca River origin (Columbia Icefield) and low diversity in Illecillewaet river (9 $\mathrm{km}$ downstream the glacier mouth). From the biogeographical point of view the dominant taxa comprised mainly widespread pioneer species coping best with the unstable conditions, while the subdominant taxa comprised taxa specific for pristine arctic-alpine or high altitude habitats (e.g., Psammothidium grischunum). Almost 50\% of the taxa were classified as oligo- to oligo-mesotraphentic and approximately $20 \%$ as endangered or extremely rare.
\end{abstract}

Key words: hydrobiology, glacial streams, oligotrophy, diatoms, biodiversity.

Received: August 2011. Accepted: October 2011.

\section{INTRODUCTION}

In mountain ranges worldwide the glaciation of drainage basins has a strong influence on the ecology of the adjacent glacial streams, specific high-alpine head-water types. Glacial streams show unique features, characterized by large seasonal and diurnal run-off fluctuations, strong longitudinal temperature gradients, restricted organic resources and temporarily enhanced sediment transport. They provide extremely harsh environments for benthic algae leading to the selection of a specific diatom species spectrum. Due to missing higher vegetation channel, shading is low and organic matter input limited (allochthonous of organic matter/nutrients). Eventual nutrient pulses originating from catchment washout are modified by temporal runoff pulses during snowmelt and/or from glacial flour during melting peak flows in summer (Rott et al. 2006).

Although several attempts were undertaken to extend the knowledge on alpine stream ecosystems (EU-funded projects: AASER - Arctic and Alpine Stream Ecosystem Research focusing on glacial stream ecosystems across Europe, Brittain et al. 2000; ARISE - A classification tool for
Alpine River and Stream Ecosystem, Brown et al. 2009, ACQWA - Assessing Climate impacts on the Quantity and quality of Water, http://www.acqwa.ch/), benthic algae are still a quite neglected component of investigations (e.g., Brittain, and Milner 2001, Cantonati et al. 2001). For high altitudes in the Alps mainly two major stream types can be differentiated, (A) kryal (glacialmelt dominated) and (B) krenal (groundwaterfed) streams (Ward 1994, Füreder 1999). The kryal stream section is characterised by constantly low temperatures $\left(\mathrm{T}_{\max }<4^{\circ} \mathrm{C}\right)$ and extreme diurnal fluctuations of run-off in summer due to the diurnal air temperature variation in high altitudes of the glaciated areas. These run-off variations can be higher than the annual runoff variations. Additional typical features are extremely turbid waters from glacial silt and low channel stability close to the glacier mouth (Milner, and Petts 1994, Ward 1994). The glaciorhithral zone adjacent to the kryal segment is highly influenced by glacial runoff at some distance from the glacier mouth providing unstable substrate, high sediment loads and low summer temperatures (Füreder 1999). 


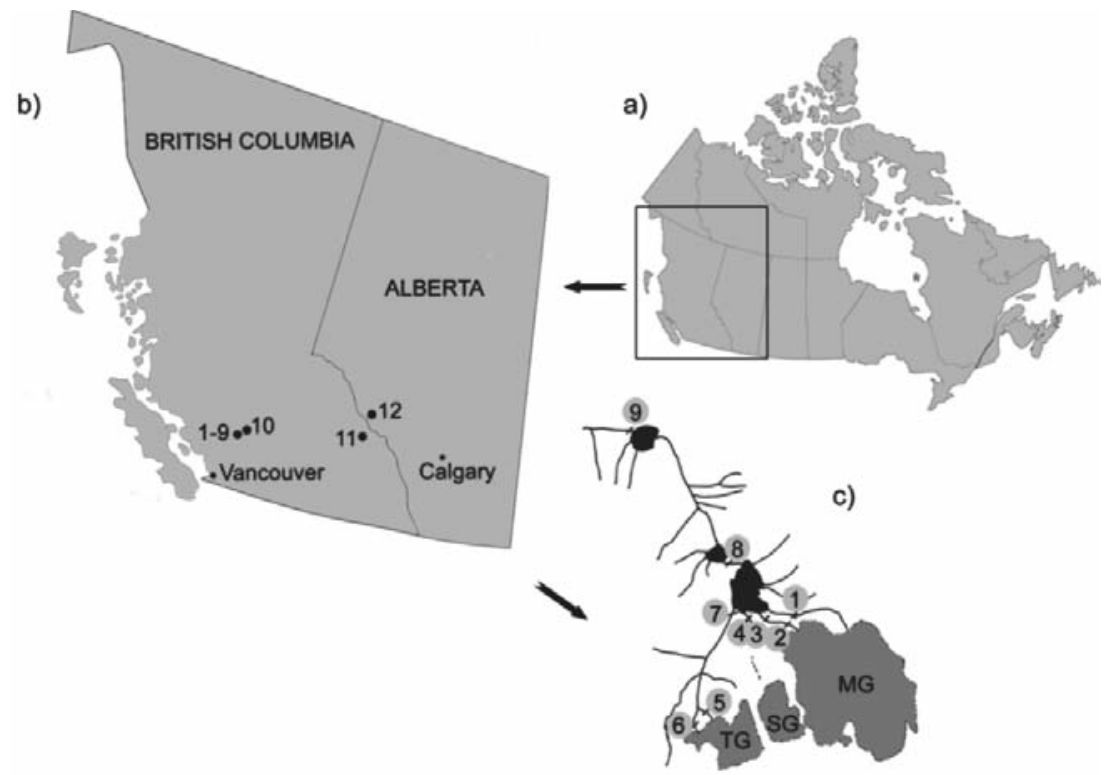

Fig. 1. Geographic location of the sampling sites (1-12) in SW Canada (British Columbia, Alberta); a) overview, b) position of the sampling sites in the provinces of British Columbia and Alberta, c) detailed map of the sites 1-9 in Joffré Lake Provincial Park (MG Matier glacier, SG - Stonecrop glacier, TG - Tszil glacier, black spots indicate Upper, Middle and Lower Joffré Lake).

Studies on benthic algae in alpine streams in general and glacial streams in particular are rare. Most recent studies were conducted in central and northern Europe dealing with the influence of glacial dynamics on benthic algae communities (e.g., Uehlinger et al. 1998; Cantonati et al. 2001; Bürgi et al. 2003; Gesierich, and Rott 2004; Hansen et al. 2006; Rott et al. 2010; Uehlinger et al. 2010) and the Himalaya (Jüttner et al. 2000). More studies on benthic algae and diatoms under extreme environment conditions were carried out in the Antarctic (e.g., Howard-Williams et al. 1986; Vincent, and Howard-Williams 1989) and Arctic region (Elster et al. 1997; Antoniades, and Douglas 2002), respectively. Although excellent expertises of diatoms from rivers in N-America have been accumulated in recent years (Anderson, and Carpenter 1998; Potapova, and Charles 2003; Bahls 2004, 2005; Carlisle et al. 2008; Potapova, and Carlisle 2011; USGS NAWQA Program 2011), small streams in pristine and remote areas, and especially glacial streams have not yet been in focus of interest, even though they can serve as remote lotic environment hotspots for biodiversity conservation (Cantonati et al. 2001). For the unglaciated Appalachians (East coast) an extended biodiversity inventory including diatoms has been made for the Great Smoky Mountains National Park (Johansen et al. 2004), representing data based on the survey of spring streams mainly from crystalline rocks serving as a reference to the present study. In multiple studies diatoms are widely used as indicators for environmental changes, in terms of climate change or acidification (e.g., Smol, and Störmer 2010), in this context complex information for low-alka- linity lakes throughout the NE United States and SE Canada are already given (Camburn, and Charles 2000).

The baseline hypotheses for the present study that only specific adapted algae may grow in glacier streams has been derived from periphyton studies of glacier streams in the European Eastern Alps (Rotmoos, Ötztal and National Park Hohe Tauern, Austria) (Rott et al. 2006). Here most algae groups except diatoms were considerably reduced in richness at distances of less than $1 \mathrm{~km}$ from the glacier mouth (Rott et al. 2006).

This actual case study therefore follows five major questions: (1) How close to the permanent ice are diatoms found in glacier streams? (2) Which taxa are present? (3) Is the taxonomic composition specific or variable? (4) Is the taxonomic composition affected by glacier size or other factors? and (5) Can glacial segments be differentiated from other sites within the river continuum?

\section{MATERIALS AND METHODS}

Twelve sites were sampled in August 2006 in SW Canada (British Columbia, Alberta) (Figs 1a and b). The sites comprise the uppermost sections of variable sized glacial streams (from a few $1 \mathrm{~s} 1$ to more than $5 \mathrm{~m}^{3} \mathrm{~s}^{-1}$ ), glacial lake outflows and a rhithral mountain river. Catchment areas and catchment glaciation varies along a broad range (1 to 99\%) (Tab. 1). Most sites (sites 1-9) were situated in Joffré Lakes Provincial Park $\left(14.6 \mathrm{~km}^{2}\right) 70 \mathrm{~km} \mathrm{SW}$ from Lillooet in the Eastern part of Coast Mountains region of British Columbia (Fig. 1c). The bedrock is composed mostly of cretaceous origin granite and granodiorite 
Tab. 1. Location and characteristics of the investigated sites (1-12). Nr: Number of the sampling site; T: stream type (GR - glaciorhithral, KR - krenal, KT - kryal turbid, R - rhithral); Alt: altitude; Size: catchment size; Glac: catchment glaciation; Run - runoff).

\begin{tabular}{|c|c|c|c|c|c|c|c|c|}
\hline Site & $\mathrm{Nr}$ & $\mathrm{T}$ & Latitude N & Longitude W & $\begin{array}{l}\text { Alt } \\
(\mathrm{m})\end{array}$ & $\begin{array}{c}\text { Size } \\
\left(\mathrm{km}^{2}\right)\end{array}$ & $\begin{array}{l}\text { Glac } \\
(\%)\end{array}$ & $\begin{array}{l}\text { Run } \\
\text { (m3) }\end{array}$ \\
\hline Matier Glacier Creek, NE & 1 & KT & $50^{\circ} 20^{\prime} 39.77^{\prime \prime}$ & $122^{\circ} 28^{\prime} 11.61^{\prime \prime}$ & 1780 & 0.49 & 48.2 & 0.2 \\
\hline Matier Glacier Creek, upper part & 2 & KT & $50^{\circ} 20^{\prime} 40.62 ”$ & $122^{\circ} 28^{\prime} 26.00^{\prime \prime}$ & 1780 & 0.89 & 92.4 & 0.1 \\
\hline Matier Glacier Creek, lower part & 3 & KT & $50^{\circ} 20^{\prime} 40.62^{\prime \prime}$ & $122^{\circ} 28^{\prime} 26.00^{\prime \prime}$ & 1600 & 0.94 & 88.0 & 0.6 \\
\hline Stonecrop glacier, SW of campground & 4 & $\mathrm{KR}$ & $50^{\circ} 20^{\prime} 40.48^{\prime \prime}$ & $122^{\circ} 28^{\prime} 35.89^{\prime \prime}$ & 1580 & 0.32 & 44.6 & 0.1 \\
\hline Tszil glacier stream NE, under waterfall & 5 & KT & $50^{\circ} 19^{\prime} 59.94 ”$ & $122^{\circ} 29^{\prime} 14.55^{\prime \prime}$ & 1900 & 0.14 & 45.0 & $<<0.1$ \\
\hline Tszil glacier mouth + snow field & 6 & KT & $50^{\circ} 19^{\prime} 50.21^{\prime \prime}$ & $122^{\circ} 29^{\prime} 20.98^{\prime \prime}$ & 1920 & 0.10 & 47.3 & $<<0.1$ \\
\hline Tszil stream down near lake & 7 & GR & $50^{\circ} 20^{\prime} 44.57^{\prime \prime}$ & $122^{\circ} 28^{\prime} 47.53 ”$ & 1580 & 1.27 & 8.9 & 0.2 \\
\hline Upper Joffre Lake outlet, cascade & 8 & GR & $50^{\circ} 21^{\prime} 04.48^{\prime \prime}$ & $122^{\circ} 28^{\prime} 49.65^{\prime \prime}$ & 1490 & 3.88 & 33.9 & 1.0 \\
\hline Outflow Lower Joffre Lake, near parking & 9 & $\mathrm{R}$ & $50^{\circ} 22^{\prime} 06.68^{\prime \prime}$ & $122^{\circ} 29^{\prime} 56.59^{\prime \prime}$ & 1210 & 5.47 & 24.0 & $1.0-2.0$ \\
\hline Cayoosh Creek & 10 & $\mathrm{R}$ & $50^{\circ} 36^{\prime} 53.67^{\prime \prime}$ & $122^{\circ} 06^{\prime} 13.92^{\prime \prime}$ & 950 & 100.00 & 1.0 & $3.0-5.0$ \\
\hline Illecillewaet, near campground & 11 & KT & $51^{\circ} 15^{\prime} 58.91^{\prime \prime}$ & $117^{\circ} 29^{\prime} 59.03^{\prime \prime}$ & 1240 & 239.20 & 34.6 & $3.0-5.0$ \\
\hline Athabasca River origin & 12 & KT & $52^{\circ} 12^{\prime} 45.30^{\prime \prime}$ & $117^{\circ} 14^{\prime} 02.15^{\prime \prime}$ & 2000 & 300.00 & 99.0 & $3.0-5.0$ \\
\hline
\end{tabular}

(British Columbia’s Online Digital Geology Map, http://www.empr.gov.bc.ca/Mining/Geoscience/BedrockM apping/Pages/BCGeoMap.aspx).

Most of these sites are strongly affected by glacial silt that is suspended in the water. Matier glacier, the largest glacier in the Joffré Group, is the origin to waters of sites $1-3$, whereas site 4 is apparently indirectly influenced by the small Stonecrop rock glacier, at $1 \mathrm{~km}$ distance from the origin with less glacial silt particles than the others. Sites 5-6 are influenced by Tszil glacier to various extend. Two sites (8 and 9) were sampled downstream the existing lake basins of Middle and Lower Joffré Lakes within pine forests. Elevation gain from site 9 at the outflow of the lowest Joffré Lake near the parking area to site 6 near the glacier mouth of Tszil Glacier is about $710 \mathrm{~m}$. The sampling area is characterised by the three small, turquoise blue Joffré lakes situated right below the massive Joffré Glacier Group.

Site 10 is located approx. $30 \mathrm{~km} \mathrm{NE}$ of Joffré area, around $10 \mathrm{~km} \mathrm{SW}$ from Lillooet in the Cayoosh Range, the northernmost section of the Lillooet Ranges in the Coast Mountains in British Columbia. Cayoosh Creek is a NE flowing tributary of the Seton River and represents a clear water mountain stream with minor glacial influence $(1 \%$ catchment glaciation) sampled at an altitude of $950 \mathrm{~m}$ a.s.1. The Illecillewaet River (site 11) as part of the Columbia River watershed, is fed by Illecillewaet Glacier in Glacier National Park $\left(1349 \mathrm{~km}^{2}\right)$ in the NW part of the Kootenay Rocky Mountains. The catchment is a mixture of marble, dolomite, limestone and shists of Cambrian to Devonian and Upper Proterozoinc to Cambrian origin bedrocks and alluvial formations in the valley including proterozoic origin diorites (British Columbia's Online Digital Geology Map, http://www. empr.gov.bc.ca/Mining/Geoscience/ BedrockMapping/ Pages/BCGeoMap.aspx).

Athabasca Glacier is positioned in Jasper National Park $\left(10,878 \mathrm{~km}^{2}\right)$, known as the largest National Park in the Canadian Rockies in Alberta. The geology of the site is re- lated to Paleozoic Cambrian to Ordovician strata of the Rockies (limestone, dolomite, quartzite and other carbonaceous minerals). Site 12 is situated approx. $100 \mathrm{~m}$ downstream the glacier mouth of Columbia Icefield at an altitude of $2000 \mathrm{~m}$ a.s.l. and is characterised by $99 \%$ catchment glaciation from a total icefield of $300 \mathrm{~km}^{2}$.

Epilithic diatoms were collected following standard procedures (e.g., European Committee for Standardization 2004), based on combined wash-samples from stones. Samples were cleaned using hydrochloric acid and 30\% hydrogen peroxide. For light microscopy (LM) the mounting of the cover slips was done using Naphrax ${ }^{\circledR}$, a mountant with a high refractive index ([R.I.]=1.74). An Olympus BX50-microscope equipped with a micro-camera (Olympus PM-C35B) was used for documentation. For scanning electron microscopy (SEM), subsamples of the diatom suspension were air-drying on glass cover slips and fixed on aluminium stubs with silver seal. The stubs were sputtercoated with gold and examined in a Hitachi S-4700 Field Emission Scanning Electron Microscope (FESEM) as well as in a Hitachi S-2600N Variable Pressure Scanning Electron Microscope (VPSEM).

The LM examinations were carried out at $\times 1000$ magnification and at the lowest taxonomical level. A minimum of 300 valves were counted per slide for calculation of the relative abundance, with the exception of Site 6 , near Tszil Glacier mouth, which was extremely poor in diatom valves (count of 100). The whole cover slip was screened after counting to characterise the actual species spectrum present at each site, and every new taxon was added to the species list with an absolute count of 1 individual (see Guidelines for biological water quality assessment in Austria: Part Phytobenthos, Pfister, and Pipp 2010). The relative abundance of each taxon was then indicated with: e - eudominant (>50\%), d - dominant (50-20.1\%), a - abundant (20-5.1\%), o - occasional (5-1\%) and s - scarce $(<1 \%)$.

The standard literature was primarily used for species identification (Krammer, and Lange-Bertalot 1986-2004, 
Lange-Bertalot, and Krammer 1989, Lange-Bertalot, and Moser 1994, Lange-Bertalot, and Metzeltin 1996, Krammer 1997a/b, Lange-Bertalot 2001) since the largest part of diatoms were widely distributed especially the artic alpine (circumpolar) taxa. In some cases of doubtful identification, the Monography on the diatoms of the United States was consulted (Patrick, and Reimer 1966). The thorough work on Achnanthidium taxa was largely based on Potapova, and Ponader (2004), Potapova, and Hamilton (2007), Ponader, and Potapova (2007) and the new online diatom identification guide of diatoms of the US (Spaulding et al. 2010, http://westerndiatoms. colorado.edu).

To provide taxonomic consistency with projects carried out in the US, terminology was based on the ANSP-2011 taxonomic system (The Academy of Natural Sciences of Philadelphia; Phycology Section, http://diatom.ansp.org/ taxaservice/). For those taxa not included in this list (9 taxa), taxa names were given according to Hofmann et al. (2011) and marked with an asterisk in the Appendix. For 2 taxa (Achnanthes pusilla, Achnanthes petersenii), we followed the taxonomy acc. to Hoffmann et al. (2011) and did not transfer them to the genus Rossithidium.

The distance from the glacier and the percentage of glaciation was calculated from geographic maps. Statistical analysis was based on SPSS 18.0 analytic software. Squared Euclidean distance was used as a measure of similarity between all cases based on presence / absence data (all 118 species). Hierarchical cluster analysis of the 12 investigated sites was carried out with Ward's linkage and Pearson's correlation coefficient has been used to measure the strength of the association between diatom richness and catchment glaciation/distance from the glacier.

\section{RESULTS}

\section{Diatom species spectrum}

Diatom identification has yielded a total of 118 diatom taxa belonging to 38 genera, several characteristic taxa are illustrated in Figs 2 and 3. The genera richest in diatom taxa were Achnanthes related taxa (21 taxa), Navicula related taxa (14 taxa) and Cymbella related taxa (12 taxa). Generally a high percentage of diatom taxa $(65 \%, 77$ taxa) occurred only once (41 taxa) or twice (36 taxa) in the data set. Most taxa found in this study $(92 \%, 108$ taxa) were recorded in the ANSP-2011 taxonomic system (The Academy of Natural Sciences of Philadelphia; Phycology Section, http://diatom.ansp.org/ taxaservice/). The most frequent taxa in the data set were the oligotraphentic taxa Hannaea arcus, Achnanthidium minutissimum, Psammothidium grischunum, Tabellaria flocculosa and the oligomesotraphentic taxon Encyonema minutum (detected in at least $83 \%$ of the samples). Firmly attached small specimens of the genera Achnanthidium, Psammothidium, Encyonema, Fragilaria and Gomphonema were common at all
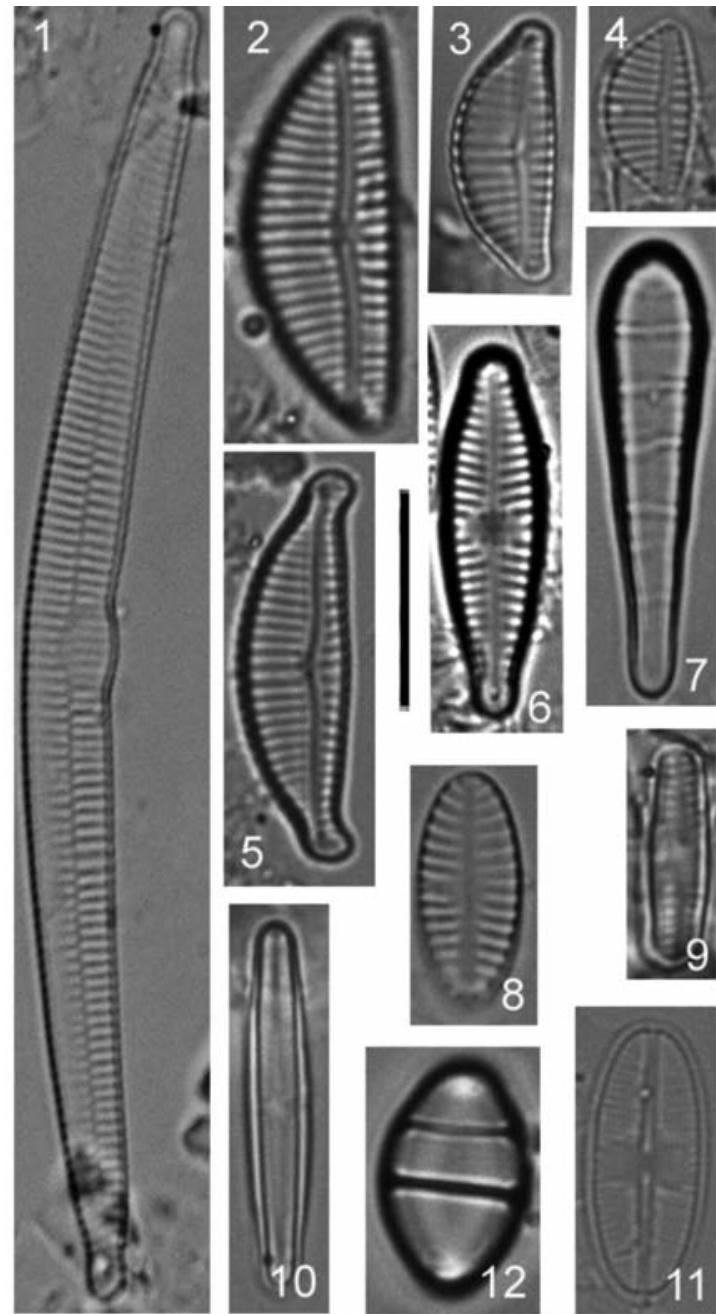

Fig. 2. Light micrographs of 12 characteristic taxa from gla-cier streams of SW Canada; 1 - Hannaea arcus, 2-4 - Encyonema minutum, 5 - Encyonema latens, 6 - Gomphonema calcifugum, 7 - Meridion circulare, 8 - Karayevia oblongella, 9 - Achnanthidium kriegeri, 10 - Achnanthidium minutissimum, 11 - Psammothidium grischunum; 12 - Diatoma mesodon, scale bar=10 $\mu \mathrm{m}$.

sites. The quantitatively dominating taxa at most sites Achnanthidium minutissimum and Hannaea arcus were present in all the samples up to maximum relative abundances of $72 \%$ and $55 \%$, respectively (Tab. 2). Species numbers ranged from 16 in the upper site of Matier Glacier creek (site 2) and in the site near Tszil Glacier mouth (site 6) to 50 in the outflow of the lowest Joffré Lake near the parking lot (site 9) (Fig. 4).

Those diatoms reaching more than $4 \%$ relative abundance in at least 1 sample (20 taxa) were chosen to represent the species spectrum (Tab. 2). Besides Achnanthidium minutissimum and Hannaea arcus were several Achnanthes related taxa (6 taxa) and Encyonema (4 taxa) characterizing the species spectrum. The oligo-mesotraphentic taxa Encyonema minutum and Encyonema silesiacum oc- 


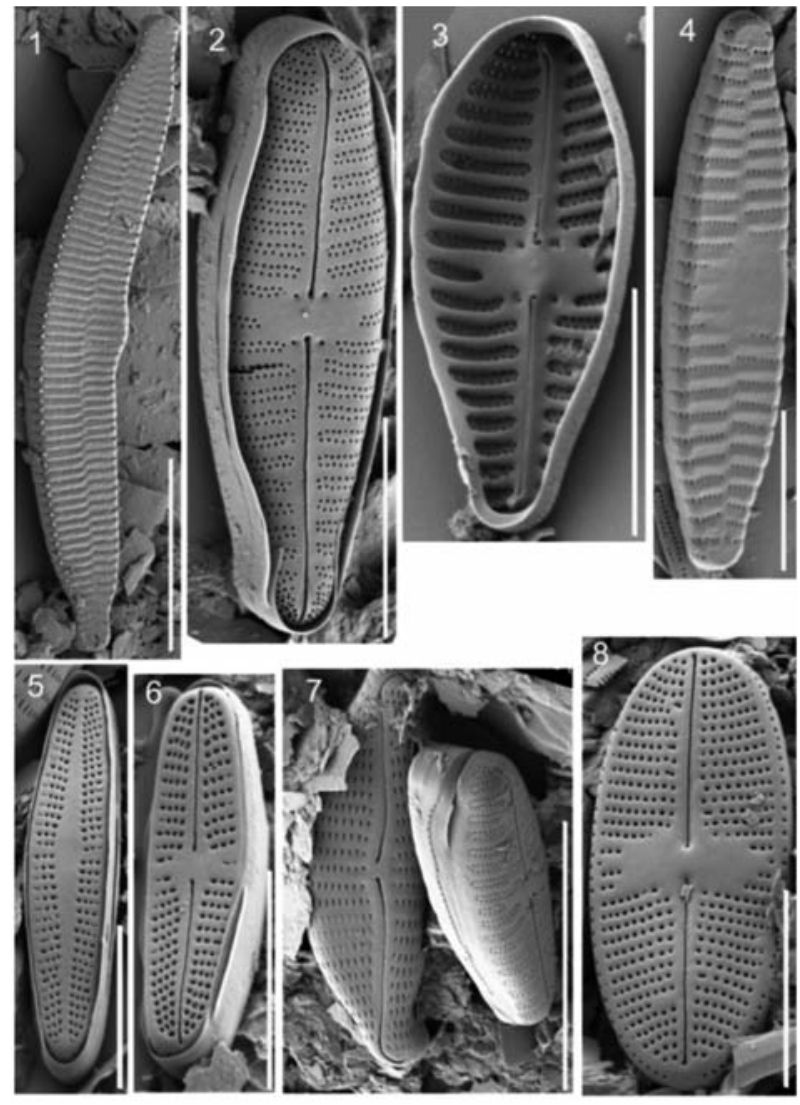

Fig. 3. Scanning electron micrographs of 6 characteristic taxa from site 4 (Stonecrop Glacier site) and 12 (Athabasca River) respectively, site numbers appear in brackets after the taxon name; 1 Hannaea arcus (12), 2+3 - Gomphonema calcifugum (4), 4 - Fragilaria vaucheriae (12), 5+6 - Achnanthidium minutissimum (4), 7 - Encyonema latens (4), 8 - Psammothidium grischunum (4), scale bar $=5 \mu \mathrm{m}$ (for numbers $1,2,7$ the scale bar equals $10 \mu \mathrm{m})$. curred in more than $2 / 3$ of the sampling sites with maximum relative abundances of $6.8 \%$ and $11.0 \%$, respectively. Encyonema latens was restricted to 3 sites only, most common at the Stonecrop Glacier site (site 4) with a relative abundance of $35.6 \%$; this scarcely recorded taxon is known from Iceland, Spitzbergen, Alaska, Lake Michigan and the highlands of Venezuela (Krammer 1997a). Encyonema neogracile is restricted to two sites only, it was found in Tszil Glacier stream in higher abundances $(11.2 \%)$.

Several small and firmly attached species of Achnanthes related taxa were found at all sites, but mainly or exclusively (15 taxa) in relative abundances $<5 \%$. The more frequent taxa Achnanthidium rivulare (5.8\%) and Achnanthidium kriegeri $(8.7 \%)$ were mostly found near the Tszil Glacier mouth (site 6), the latter occurred also in the upper part of Matier Glacier creek (site 2) with a proportion of 12.1\%. Psammothidium grischunum (24.4\%) and Achnanthes pusillum (5.4\%) were characterizing the diatom assemblage further downstream in Tszil Glacier stream (site 5). Achnanthes petersenii was the dominating taxon in Illecillewaet River (site 11) with a relative abundance of $65.8 \%$, a rarely recorded taxon at calcareous oligotrophic (up to mesotrophic) sites. In addition to these taxa Gomphonema calcifugum (oligo-mesotraphentic) and Fragilaria vaucheriae as well as Diatoma ehrenbergii/D. vulgaris are worth mentioning, the latter were restricted to Cayoosh Creek (site 10, 42.4\% and 5.5\%). Gomphonema calcifugum was found at various sites, reaching highest abundances near the Stonecrop glacier (site 4, 25.4\%), whereas Fragilaria vaucheriae was frequent in the Upper Joffré Lake outlet $(8.2 \%)$ and in Athabasca River (6.5\%).

Trophic preferences were found from the literature for

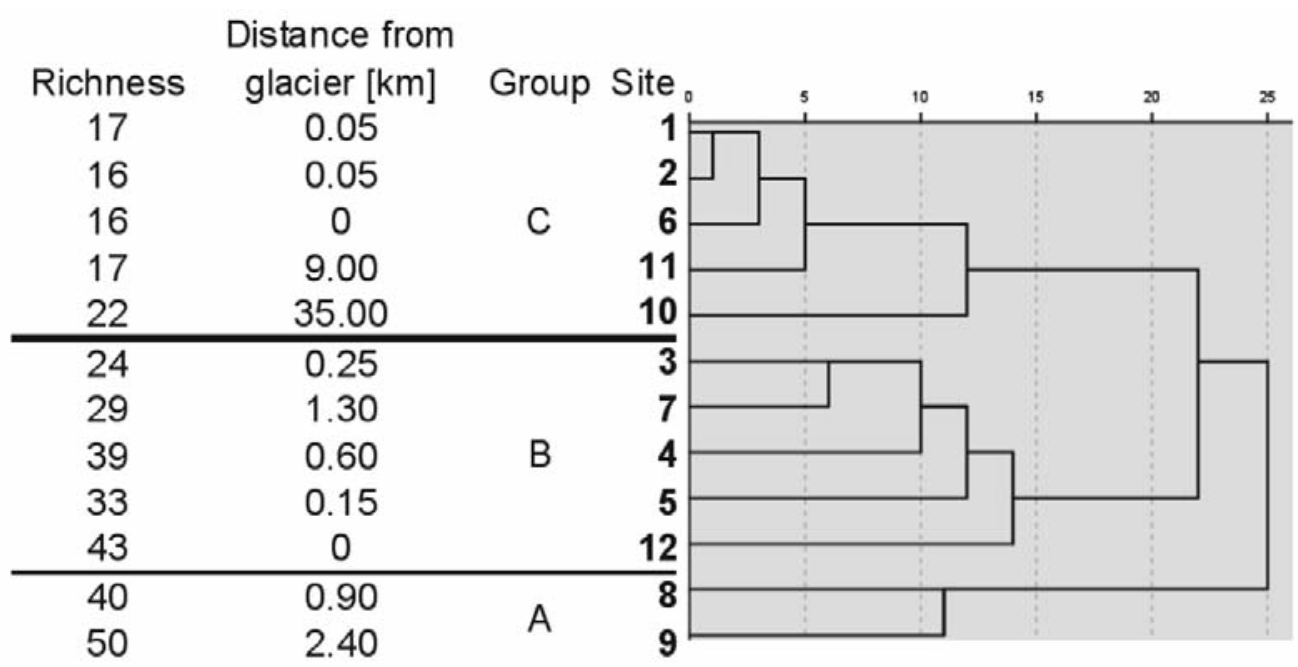

Fig. 4. Hierarchical clustering of 3 major groups of sites according to their diatom species composition using Ward's linkage together with some information on diatom richness (= total number of taxa incl. single individuals) and the site's distance from glacier. 
Tab. 2. Diatom species composition of 12 Canadian glacier streams. Ordination of samples and species according to cluster analysis (sample cluster see Fig. 4; taxa with relative abundance $>4 \%$ in at least 1 sample); abundances given as 5 abundance classes: e - eudominant (>50\%); d - dominant (50-20.1\%); a - abundant (20-5.1\%); o - occasional (5-1\%); s - scarce (<1\%); for explanation of site numbers see Tab. 1.

\begin{tabular}{|c|c|c|c|c|c|c|c|c|c|c|c|c|}
\hline Site & 1 & 2 & 6 & 11 & 10 & 3 & 7 & 4 & 5 & 12 & 8 & 9 \\
\hline Hannaea arcus & $\mathrm{e}$ & $\mathrm{s}$ & $\mathrm{a}$ & o & o & $\mathrm{e}$ & $\mathrm{d}$ & $\mathrm{a}$ & o & $\mathrm{d}$ & $\mathrm{d}$ & $\mathrm{s}$ \\
\hline Achnanthidium minutissimum & $\mathrm{a}$ & e & $\mathrm{e}$ & $\mathrm{a}$ & $\mathrm{a}$ & $\mathrm{a}$ & $\mathrm{a}$ & $\mathrm{a}$ & $\mathrm{d}$ & $\mathrm{d}$ & $\mathrm{d}$ & $\mathrm{a}$ \\
\hline Psammothidium grischunum & o & o & o & $\mathrm{s}$ & & $\mathrm{s}$ & $\mathrm{s}$ & o & $\mathrm{d}$ & $\mathrm{s}$ & $\mathrm{s}$ & $\mathrm{s}$ \\
\hline Encyonema minutum & $\mathrm{a}$ & o & o & $\mathrm{s}$ & o & & o & o & $\mathrm{a}$ & o & $\mathrm{s}$ & $\mathrm{s}$ \\
\hline Tabellaria flocculosa & $\mathrm{s}$ & o & & o & & $\mathrm{s}$ & $\mathrm{a}$ & $\mathrm{s}$ & $\mathrm{s}$ & o & $\mathrm{s}$ & $\mathrm{e}$ \\
\hline Achnanthidium kriegeri & $\mathrm{o}$ & $\mathrm{a}$ & $\mathrm{a}$ & o & & & $\mathrm{s}$ & $\mathrm{s}$ & o & & & $\mathrm{s}$ \\
\hline Encyonema silesiacum & $\mathrm{s}$ & & & & $\mathrm{a}$ & $\mathrm{s}$ & $\mathrm{a}$ & o & & $\mathrm{a}$ & $\mathrm{s}$ & $\mathrm{s}$ \\
\hline Meridion circulare & $\mathrm{a}$ & & & & & $\mathrm{s}$ & $\mathrm{s}$ & $\mathrm{s}$ & $\mathrm{s}$ & $\mathrm{s}$ & $\mathrm{s}$ & $\mathrm{s}$ \\
\hline Achnanthidium rivulare & & o & $\mathrm{a}$ & & & $\mathrm{s}$ & & $\mathrm{s}$ & $\mathrm{s}$ & $\mathrm{s}$ & $\mathrm{s}$ & \\
\hline Gomphonema calcifugum & & & & & & $\mathrm{s}$ & $\mathrm{s}$ & $\mathrm{d}$ & o & o & o & $\mathrm{s}$ \\
\hline Achnanthes pusilla & & & o & & & & & $\mathrm{s}$ & $\mathrm{a}$ & $\mathrm{s}$ & $\mathrm{s}$ & $\mathrm{s}$ \\
\hline Fragilaria vaucheriae & & & & & o & $\mathrm{s}$ & $\mathrm{s}$ & & & $\mathrm{a}$ & $\mathrm{a}$ & o \\
\hline Achnanthidium linearioides & & o & & $\mathrm{s}$ & & & $\mathrm{s}$ & & & & & $\mathrm{s}$ \\
\hline Achnanthes petersenii & & & & e & & $\mathrm{s}$ & o & & & & & \\
\hline Encyonema latens & & & & & & o & & $\mathrm{d}$ & & $\mathrm{a}$ & & \\
\hline Gomphonema olivaceum & & & & & o & & & & & $\mathrm{s}$ & & \\
\hline Nitzschia fonticola & & & & & o & & & & & $\mathrm{s}$ & & \\
\hline Diatoma ehrenbergii & & & & & $\mathrm{d}$ & & & & & & & \\
\hline Diatoma vulgaris & & & & & $\mathrm{a}$ & & & & & & & \\
\hline
\end{tabular}

$78 \%$ of the diatom taxa (93 taxa). Half of the taxa (49\%) were classified as oligotraphentic (4\% ultraoligo-traphentic, $27 \%$ oligotraphentic, $18 \%$ oligo-mesotraphentic) and mesotraphentic (16\%), another $27 \%$ as mesoeutraphentic (15\%) and eutraphentic (12\%). Only a very small proportion was classified with a preference for eupolytraphentic (5\%) and polytraphentic conditions (2\%) (Rott et al. 1999). Based on the Red List of algae for Germany (Lange-Bertalot, and Steindorf 1996) 103 diatom taxa (87\%) could be classified with $21 \%$ (22 taxa) as endangered to various extend (critically endangered - 1 taxon, strongly endangered - 1 taxon, endangered - 11 taxa, extremely rare - 6 taxa, potentially endangered - 3 taxa). A large proportion of arctic-alpine diatom species in the subdominant taxa was characterizing the data set.

Classification of sites based on diatom species composition

From hierarchical cluster analysis of all sites based on presence / absence data including all 118 species found, three distinct groups (A-C) of sites were classified (Fig. 4). This differentiation of the major groups displays characters reflected mainly by the relative proportions of the different hydrological stream types: lake outlet, glacial (kryal) streams and krenal (spring fed) streams, respectively.

\section{GROUP A - lake outlets}

The first group of sites, separated from the other sites on the first division level, was formed by the two lake outlets of Middle and Lower Joffré Lakes (sites 8, 9). These sites were characterised by the highest diatom richness within the Coast Mountain samples. The species spectrum from both sites showed beside typical stream taxa as Achnanthidium minutissimum and Hannaea arcus, small amounts of planktonic centric taxa (mostly Cyclotella species) and a dominance of Tabellaria flocculosa, a common littoral diatom, at the lower lake outlet (site 9).

GROUP B - upper stream segments with different runoff sources

Group B was characterised by higher relative abundances of Achnanthidium minutissimum and Hannaea arcus accompanied by several taxa defining the subgroups. The small proportions of the crenophilous taxa Meridion circulare and Diatoma mesodon as well as Tabellaria flocculosa, typical for low mineral content, indicated the influence of different runoff sources (ground water?).

Sites 3 and 7 (Matier glacier creek lower part, Tszil stream downstream near lake) showed highest relative abundances of Hannaea arcus dominating at site 3, but H. arcus accompanied by Diatoma mesodon, Tabellaria flocculosa and Encyonema silesiacum at Site 7. Site 4 fed by stonecrop rock glacier was characterised by Encyonema latens and Gomphonema calcifugum. The species spectrum at site 5 (Tszil stream NE) was dominated by Achnanthidium minutissimum, Psammothidium grischunum and Encyonema neogracile, whereas at site 12 (Athabasca River) Achnanthidium minutissimum was prevailing together with Hannaea arcus. 
GROUP C - hypokryal/glaciorhithral stream segments

All sites in Group C showed varying abundances of the typical stream taxa Achnanthidium minutissimum, Encyonema minutum and Hannaea arcus. Sites 1, 2 and 6 located directly at or close by the glacier mouth (site 1 and 2 adjacent to Matier Glacier, site 6 close to Tszil Glacier mouth) were characterised by higher amounts of Achnanthidium kriegeri and Psammothidium grischunum. Site 1 might have been influenced by spring (ground) water input indicated by higher abundances of Meridion circulare. Adjacent to these three hypokryal sites there was a grouping of site 11 (Illecillewaet River) and site 10 (Cayoosh Creek), both represented the most distant sites from the glacial outflow. Site 11 was dominated by the oligotraphentic taxon Achnanthes petersenii. Site 10 reflected changes of diatom communities along alpine rivers with a shift from small, adhesive taxa of the Achnanthes related taxa group (except Achn. minutissimum $12 \%$ rel. abundance at site 10) to a dominance of the chainforming taxa Diatoma spp. (Diatoma ehrenbergii dominant, D. vulgaris) and a sub-dominance of Encyonema spp. (Encyonema silesiacum, Encyonema minutum), Nitzschia spp. (Nitzschia fonticola, Nitzschia dissipata), Fragilaria vaucheriae, Reimeria sinuata and Gomphonema olivaceum (these 9 taxa account for $80 \%$ rel. abundance).

Longitudinal variation in species richness

For analysing the relationship between diatom species richness and glaciation of the catchment as well as distance from glacier, sites 1 to 6 in Joffré Lakes Provincial Park have been chosen, for their geographic position is $<1 \mathrm{~km}$ from the glacier mouth (Fig. 1). The existing lake basin downstream the Upper Joffré Lake had a specific effect in alteration of diatom species composition, therefore site 8 , although less than $1 \mathrm{~km}$ from the glacier mouth, was excluded from the data set. The total number of diatoms species for the small streams close to the glacier mouth displayed a significant positive relationship with distance from the glacier (Fig. 5) irrespective of catchment glaciation $(\mathrm{r}=0.176)$.

The Athabasca River origin - a special habitat

The taxa richness in Athabasca River at the glacier mouth (site 12) exceeded the expected results from the Austrian Alps with 43 diatom taxa recorded. It is most likely that the actual number of diatoms may be even higher than the one detected, since most of the taxa were detected only once in the slide $(59 \%, 26$ taxa). Nine species occurred in relative abundances $>1 \%$ with Achnanthidium minutissimum dominating, accompanied by the rheophilous taxon Hannaea arcus, the nordic taxon Encyonema latens, Encyonema silesiacum and Fragilaria vaucheriae (Tab. 3).

Five taxa were restricted to this glacial outflow
(Achnanthidium jackii, Amphora inariensis, Encyonema mesianum, Diploneis ovalis, and Staurosirella pinnata group). Encyonema mesianum is a rarely found taxon in oligotrophic, electrolyte-poor habitats in high alpine regions.

The most species rich group amongst the 35 taxa reaching relative abundances $<1 \%$ are the Achnanthes related taxa with 6 different genera (Psammothidium grischunum, P. helveticum, Eucocconeis laevis, Planothidium lanceolatum, P. dubium, Achnanthidium jackii, A. rivulare, Karayevia oblongella, Achnanthes pusillum) and Nitzschia spp. (Nitzschia bryophila, N. cf. perminuta, N. dissipata, N. fonticola, N. pura, N. sublinearis).

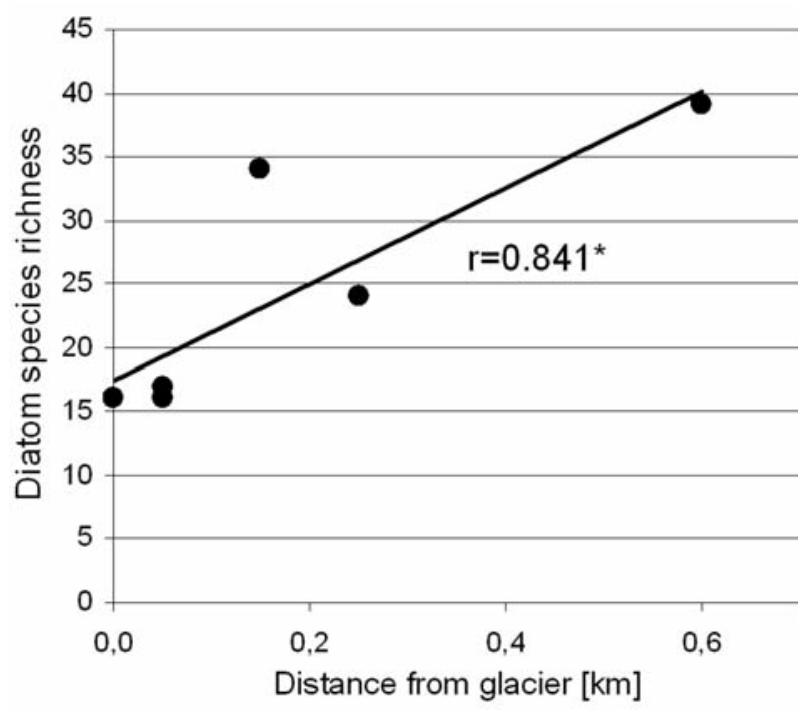

Fig. 5. Relationship between total species richness of diatoms and distance from glacier mouth in $\mathrm{km}$ for the 6 glacial stream sites in Joffré Lakes Provincial Park at distances of $<1 \mathrm{~km}$ from the glacier mouth (sites 1 to 6 ); $r$ - Pearson's Correlation Coefficient, $*=$ significant $(p<0.05)$.

Tab. 3. Diatom composition ( $>1 \%$ relative abundance) and their relative abundance (\%) from Athabasca River origin at Columbia ice field.

\begin{tabular}{lc}
\hline Taxon & $\%$ \\
\hline Achnanthidium minutissimum & 30.8 \\
Hannaea arcus & 25.9 \\
Encyonema latens & 8.7 \\
Encyonema silesiacum & 8.2 \\
Fragilaria vaucheriae & 6.5 \\
Encyonema minutum & 2.7 \\
Gomphonema calcifugum & 1.9 \\
Fragilaria tenera & 1.6 \\
Tabellaria flocculosa & 1.1 \\
\hline
\end{tabular}




\section{DISCUSSION}

The findings from Canadian glacial streams confirmed our hypothesis that environmental conditions in turbid glacial streams seem to select specific attached algal communities (Gesierich, and Rott 2004). Although rarely recorded until now (e.g., Jüttner et al. 2000; Cantonati et al. 2001; Gesierich, and Rott 2004; Rott et al. 2006), diatoms were well represented in all types of glacier streams even with peak flows in summer (with very variable runoff!) and very close to the glacier mouth.

The dominant species found in the Canadian glacier streams corresponded in most cases to findings from other glaciated mountain areas worldwide with two dominants: the pioneer taxon Achnanthidium minutissimum together with the rheobiontic Hannaea arcus (e.g., Cantonati et al. 2001), but contrasted to cryoconite holes dominated by other diatom taxa (e.g. Diadesmis, Mayamaea, Navicula, Luticola, Muelleria) more related to still water situations (Müllner et al. 2001; Yallop, and Anesio 2010). The nominate variety of the rheobiontic Hannaea arcus however is not an exclusive taxon of glacier streams since it was common in most other fast flowing streams in arctic, antarctic and Alaska (Milner et al. 1992; Beyens, and van de Vijver 2000). We did not encounter the expected variety recta of Hannaea arcus, although reported as fairly common for cold circumpolar situations and the Himalaya region (Cantonati et al. 2001). Although Achnanthidium minutissimum is supposed to be a widespread taxon, it comprises a variety of ecomorphs that have specific adaptive capacities to grow under oligotrophic cold water conditions (Potapova, and Hamilton 2007 - 6 morphotypes of $A$. minutissimum within a data set of 728 specimens of North American Rivers). Since the major taxonomic revisions of the Achnanthes related taxa, information on the autecological and biogeographical distribution of the new taxa is scarce. The presence of several Achnanthes related taxa (Achnanthes, Achnanthidium, Eucocconeis, Karayevia, Planothidium, Psammothidium) with variable ecological demands in the streams observed seemed to underpin the specific situation found here. For example, Achnanthidium minutissimum present at all sites, is preferring low nutrient and ionic content, whereas Achnanthidium rivulare, found with slightly higher abundances in two sites in the Coast Range, is mainly recorded from low calcium, high chloride, phosphorus poor soft waters (Potapova, and Ponader 2004; Ponader, and Potapova 2007).

Despite high variability of catchment glaciation and fundamentally different geological conditions between the Coast Range sites and the Rocky Mountain sites there was a specific diatom species composition in high altitude turbid glacial streams that corresponded to streams in the Eand SE-Alps ( $>60 \%$ of the most common diatoms from 42 high altitude turbid glacial streams in E- and SE-Alps match with the present study in Canadian glacial streams), including several characteristic taxa e.g. Achnanthidium minutissimum, Diatoma mesodon, Encyonema minutum, Gomphonema calcifugum, Hannaea arcus, Meridion circulare and Staurosirella pinnata (Rott et al. 2006).

A similarity of the characteristic taxa was even found when the present results were compared with the algal species records for the spring streams in the Great Smoky Mountains National Park (Johansen et al. 2004) with a lower proportion of $32 \%$ taxa in common. Specific arcticalpine elements of the diatom flora (Achnanthes petersenii, Encyonema latens and Gomphonema calcifugum) seemed to be common not only in glacier streams but also in arctic meltwater streams and small brooks (Van de Vijver et al. 2003) as well as in moss samples and shallow lotic sites with low current (pre-sumably being able to survive periods of desiccation, Antoniades, and Douglas 2002). Encyonema latens was also reported from a glacial pool formed by flooding of the surrounding area at high meltwater input from a glacial stream in the arctic (Elster et al. 1997), whereas Gomphonema calcifugum was prevailing at some sites in the Himalaya together with Diatoma mesodon (Cantonati et al. 2001).

It is known that algal assemblages are partly regulated by catchment characteristics (Pipp, and Rott 1993; Rott et al. 1997, 1999; Rott et al. 2006). Geology however seemed not to be of primary importance in these Canadian streams, since high variability of catchment glaciation and fundamentally different geological conditions between the Coast Range sites and the Rocky Mountain sites showed a quite similar diatom composition. Although clear changes of the diatom flora along the river continuum were observed in the Coast range, it was not primarily the size of the glacier and the geology but the site's distance from the glacier and the related changes in the hydrological regime that shaped diatom species composition most.

Apparently in those glacier streams, larger already at the outflow of the glacier, fast current and strong flow variations accounted for a more diverse community (see Athabasca River). Hydrology in turbid glacier streams including scouring by sediment load may have had a negative effect on benthic algal growth and species selection, whereas nutrient input (generally phosphorus), mainly washed out as glacial flour (produced by the mechanical action of the glacier ice to the ground) positively affected algae species in the Alps and other mountain ranges in moderate latitudes (Bürgi et al. 2003; Gesierich, and Rott 2004; Rott et al. 2006; Uehlinger et al. 2010). Particularly small celled diatoms with specific adaptation to live within the viscous sub layer close to the substrate (normally $<<1$ $\mathrm{mm}$ thick) can sustain these extreme environment conditions.

Strong water level fluctuations, dynamic discharge patterns, flood pulses and instable substrate cause lower densities of algae and seem to favour small taxa with low 
biomass like the primary colonizer Achnanthidium minutissimum apparently firmly attached to stone substrates with the araphid valves (Peterson, and Stevenson 1992). Generally the diatoms at kryal sites (e.g., Achnanthidium, Psammothidium, Encyonema, Gomphonema) are nonmotile and can resist the harsh hydraulic conditions with strong attachment abilities and their capability to live in the boundary layer near the surface or living attached to the substrate by mucilage or mucilaginous stalks. To some degree, due to their small size, they may be resistant to ingestion by grazers, like the cold-stenothermal chironomid species of the subfamily Diamesinae (Füreder et al. 2000, 2001).

\section{CONCLUSIONS}

The results of this study and in particular the generally lower diatom species number close to the glacier mouth raise several open questions for future investigations in these remote areas.

1) How fast can diatom pioneers reach recently formed streams in glacier retreat areas? Which taxa arrive first?

2) Is the species spectrum a consequence of stream size and hydraulic conditions or other factors (channel features, nutrients from glacial flour, topography etc.)?

3) Are the diatom taxa from glacier streams psychrophilic (=cold loving)? If diatoms restricted to low temperatures exist, climate change would cause a considerable threat (Harte et al. 2004; Thomas et al. 2004).

4) What would happen if most glacier streams would dry off in summer? Essential elements of the diatom flora may disappear.

5) What are the effects of shrinking glaciers, decreasing melt-water input and increasing water temperature on diatom growth and closely related kryal grazers (e.g., several species within the genus Diamesa)?

\section{ACKNOWLEDGMENTS}

We acknowledge the support for a scientific leave to the second author by the Institute of Botany of the University of Innsbruck (Univ. Prof. Dr Sigmar Bortenschlager), the Canadian Studies Centre (Univ. Prof. Dr Ursula MoserMathis) and the Vice-Rectorate for Research (Univ. Prof. Dr Dr hc Tilmann Märk). The working facilities to perform this study (especially the SEM and part of the LM studies) were partly provided by Prof. J. Richardson, Department of Forest Sciences, Stream, Riparian Research Laboratory at UBC (University of British Columbia) Vancouver. We are grateful to Dr. Peter Pfister (ARGE Limnologie, Innsbruck) for solving delicate taxonomic problems and Werner Kofler for a thorough discussion of the manuscript. We thank the anonymous referee for carefully reading the paper and providing thoughtful comments.

\section{REFERENCES}

Anderson CW, and Carpenter KD. 1998. Water quality and algal conditions in the North Umpqua River Basin, Oregon, 199295, and implications for resource management. Geological Survey Water-Resources Investigations Report 98-4125. U.S. Department of The Interior, Geological Survey. Portland, OR.

Antoniades D, and Douglas MSV. 2002. Characterization of high arctic stream diatom assemblages from Cornwallis Island, Nunavut, Canada. Can. J. Bot. 80(1): 50-58. 10.1139/ b01-133.

Bahls LL. 2004. Northwest Diatoms 1: A Photographic Catalogue of Species in the Montana Diatom Collection, with Ecological Optima, Associates, and Distribution Records for the Nine Northwestern United States. Hannaea. Helena, MT.

Bahls LL. 2005. Northwest Diatoms 2: A Photographic Catalogue of Species in the Montana Diatom Collection, with Ecological Optima, Associates, and Distribution Records for the Nine Northwestern United States. Hannaea. Helena, MT.

Beyens L, and Van de Vijver B. 2000. First contribution to the diatom flora of High Arctic Hopen Island (Svalbard). Nova Hedwigia 70: 409-424.

Brittain JE, and Milner AM. 2001. Ecology of glacierfed rivers: current status and concepts. Freshwater Biol. 46: 1571-1578.

Brittain JE, Adalsteinsson H, Castella E, Gislason GM, Lencioni V, Lods-Crozet B, Maiolini B, Milner AM, Petts GE, and Saltveit SJ. 2000. Towards a conceptual understanding of arctic and alpine streams. Verh. Internat. Verein Limnol. 27: 740743.

Brown LE, Hannah DM, and Milner AM. 2009. ARISE: A classification tool for Alpine RIver and Stream Ecosystem management. Freshwater Biol. 54: 1357-1369.

Bürgi HE, Burgherr P, and Uehlinger U. 2003. Aquatic flora. In: Ward JV, and Uehlinger U (Eds), Ecology of a Glacial Floodplain. Kluwer Academic Press, Dordrecht: 139-151.

Camburn KE, and Charles DF. 2000. Diatoms of low-alkalinity lakes in the north eastern United States. The Academy of Natural Sciences of Philadelphia, Scientific Publications, Philadelphia, USA. Special Publication 18: 152 pp.

Cantonati M, Corradini G, Jüttner I, and Cox EJ. 2001. Diatom assemblages in high mountain streams of the Alps and the Himalaya. Nova Hedwigia, Beiheft 123: 37-61.

Carlisle DM, Hawkins CP, Meador MR, Potapova M, and Falcone J. 2008. Biological assessments of Appalachian streams based on predictive models for fish, macroinvertebrate, and diatom assemblages: J. North. Am. Benthol. Soc. 27/1: 16-37.

Elster J, Svobody J, Komárek J, and Marvan P. 1997. Algal and cyanoprocaryote communities in a glacial stream, Sverdrup Pass, $79^{\circ} \mathrm{N}$, Central Ellesmere Island, Canada. Algological Studies / Arch. Hydrobiol. Suppl. 85: 57-93.

European Committee for Standardization. 2004. Water qualityguidance standard for the identification, enumeration and interpretation of benthic diatom samples from running waters. EN 14407:2004. Geneva. European Committee for Standardization.

Füreder L. 1999. High alpine streams: cold habitats for insect larvae. In: Margesin R., and F. Schinner (Eds), Cold Adapted Organisms. Ecology, Physiology, Enzymology and Molecular Biology. Springer-Verlag, Berlin: 181-196.

Füreder L, Schütz C, Burger R, and Wallinger M. 2000. Seasonal abundance and community structure of Chironomida in two 
contrasting high alpine streams. Freshwater Biol. 46: 16731690.

Füreder L, Schütz C, Wallinger M, and Burger R. 2001. Physicochemistry and aquatic insects of a glacierfed and a springfed alpine stream. Freshwater Biol. 46: 1673-1690.

Gesierich D, and Rott E. 2004. Benthic algae and mosses from aquatic habitats in the catchment of a glacial stream (Rotmoos, Ötztal, Austria). Berichte des naturwissenschaftlich medizinischen Vereins Innsbruck, 91: 7-42.

Hansen I, Gislason GM, and Ólafsson JS. 2006. Diatoms in glacial and alpine rivers in Central Iceland. Verh. Internat. Verein. Limnol. 29: 1271-1274.

Harte J, Ostling A, Green JL, and Kinzig A. 2004. Climate change and extinction risk. Nature 427: 145-148. doi: 10.1038/nature 02718 .

Hofmann G, Werum M, and Lange-Bertalot H. 2011. Diatomeen im Süßwasser-Benthos von Mitteleuropa. Bestimmungsflora Kieselalgen für die ökologische Praxis. Über 700 der häufigsten Arten und Ökologie. Gantner Verlag: 908 pp.

Howard-Williams C, Vincent CL, Broady PA, and Vincent WF. 1986. Antarctic stream ecosystems: variability in environmental properties and algal community structure. Int. Rev. Hydrobiol. 71: 511-544.

Johansen JR, Lowe RL, Gomez SR, Kociolek JP, and Makosky SA. 2004. New algal species records for the Great Smoky Mountains National Park, U.S.A., with an annotated checklist of all reported algal species for the park. Algological Studies 111: $17-44$

Jüttner I, Cox EJ, and Ormerod SJ. 2000. New or poorly known diatoms from Himalayan streams. Diatom Res. 15(2): 237262.

Krammer, K. 1997a. Die cymbelloiden Diatomeen. Teil 1. Allgemeines und Encyonema Part. Bibl. Diatomol. 36: 382 pp. J. Cramer, Berlin, Stuttgart.

Krammer K. 1997b. Die cymbelloiden Diatomeen. Teil 2. Encyonema part., Encyonopsis and Cymbellopsis. Bibl. Diatomol.,37: 469 pp. J. Cramer, Berlin, Stuttgart.

Krammer K, and Lange-Bertalot H. 1986-2004. Süßwasserflora von Mitteleuropa (H. Ettl, J. Gerloff, H. Heynig, and Mollenhauer, D., Eds), Bacillariophyceae, Naviculaceae, 2/1: 876 pp.; Bacillariaceae, Epithemiaceae, Surirellaceae, 2/2: 596 pp.; Centrales, Fragilariaceae, Eunotiaceae, 2/3: 576 pp.; Achnanthaceae, 2/4: 468 pp. G. Fischer, Stuttgart, New York.

Lange-Bertalot H. 2001. Navicula sensu stricto. 10 Genera separated from Navicula sensu lato. Frustulia. Diatoms of Europe, 2: 526 pp. (Gantner) Ruggell.

Lange-Bertalot H, and Krammer K. 1989. Achnanthes. Eine Monographie der Gattung. Bibl. Diatomol. 18: 393 pp. J. Cramer. Berlin, Stuttgart.

Lange-Bertalot H, and Metzeltin D. 1996. Indicators of Oligotrophy; 800 taxa representative of three ecologically distinct lake types. Iconogr. Diatomol. 2: 390 pp. Koeltz, Koenigstein.

Lange-Bertalot H, and Moser G. 1994. Brachysira. Monographie der Gattung. Wichtige Indikator-Species für das GewässerMonitoring und Naviculadicta nov. gen. Ein Lösungsvorschlag zu dem Problem Navicula sensu lato und Navicula sensu stricto. Bibl. Diatomol. 29: 212pp. (J. Cramer) Berlin, Stuttgart.

Lange-Bertalot H, and Steindorf A. 1996. Rote Liste der limnischen Kieselalgen (Bacillariophyceae) Deutschlands.
Schriftenreihe für Vegetationskunde 28: 633 - 677.

Milner AM, and Petts GE. 1994. Glacial rivers: Physical habitat and ecology, Freshwater Biol. 42: 295-307.

Milner AM, DeOliveira MCP, and Gibeau G. 1992. Epilithic diatom community response to years of PO4 fertilization: $\mathrm{Ku}-$ paruk River, Alaska (68 N Lat.). Hydrobiologia 240: 103-119.

Müllner DR, Warwick FV, Pollard WH, Fritsen CH. 2001. Glacial cryoconite ecosystems: A bipolar comparison of algal communities and habitats. Nova Hedwigia Beiheft 123: 173-197.

Patrick R, and Reimer CW. 1966. The diatoms of the United States, exclusive of Alaska and Hawaii 1 - Fragilariaceae, Eunotiaceae, Achnanthaceae, Naviculaceae. Monographs of the Academy of Natural Sciences of Philadelphia 13: 688 pp.

Peterson CG, and Stevenson RJ. 1992. resistance and resilience of lotic algal communities: importance of disturbance timing and current. Ecology 73: 1445-1461.

Pfister, P., and E. Pipp. 2010. Leitfaden zur Erhebung der biologischen Qualitätselemente, Teil A3 - Phytobenthos, BMLFUW, ISBN: 978-3-85174-061-5 Version Nr.: A3-01h_PHB

Pipp E, and Rott E. 1993. Ökologische Wertigkeit von Fließgewässern in Österreich nach dem Algenaufwuchs. Blaue Reihe des Bundesministeriums f. Umwelt, Jugend und Familie 2. ISBN 3-901412-01-8.

Ponader KC, and Potapova MG. 2007. Diatoms from the genus Achnanthidium in flowing waters of the Appalachian Mountains (North America): Ecology, distribution and taxonomic notes. Limnologica, 37: 227-241.

Potapova M, and Charles DF. 2003. Distribution of benthic diatoms in U.S. rivers in relation to conductivity and ionic composition. Freshwater Biol. 48/8: 1311-1328.

Potapova MG, and Carlisle DM. 2011. Development and application of indices to assess the condition of benthic algal communities in U.S. streams and rivers: U.S. Geological Survey Open File Report 2011-1126: 40 pp.

Potapova MG, and Hamilton PB. 2007. Morphological and ecological variation within the Achnanthidium minutissimum (Bacillariophyceae) species complex. J. Phycol. 43, 561-575. DOI: $10.1111 /$ j.1529-8817.2007.00332.x

Potapova MG, and Ponader KC. 2004. Two common North American diatoms, Achnanthidium rivulare sp. nov. and A. deflexum (Reimer) Kingston: morphology, ecology and comparison with related species. Diatom Res. 19(1): 33-57.

Rott E, Gesierich D, and Binder N. 2010. Lebensraumtypen und Diversitätsgradienten lotischer Algen in einem Gletschereinzugsgebiet. In: E.M. Koch, and B. Erschbamer (Eds), Glaziale und periglaziale Lebensräume im Raum Obergurgl: 203-212. Innsbruck Univ. Press. ISBN 978-3-902719-50-8.

Rott E, Cantonati M, Füreder L, and Pfister P. 2006. Benthic algae in high altitude streams of the Alps - a neglected component of aquatic biota. In: A. Lami, and A. Boggero (Eds), Ecology of high altitude aquatic systems in the Alps. Hydrobiologia 562: 195-216.

Rott E, Hofmann G, Pall K, Pfister P, and Pipp E. 1997. Projekt BMLF: Indikationslisten für Aufwuchsalgen in Fließgewässern in Österreich. Teil 1: Saprobielle Indikation. Bundesministerium für Land- und Forstwirtschaft, Wasserwirtschaftskataster, Wien. ISBN 3-85 174-017-03. 73 pp.

Rott E, Pipp E, Pfister P, vanDam H, Ortler K, Binder N, and Pall K. 1999. Indikationslisten für Aufwuchsalgen in österreichischen Fließgewässern. Teil 2: Trophieindikation sowie geo- 
chemische Präferenz, taxonomische und toxikologische Anmerkungen. Bundesministerium für Land- und Forstwirtschaft, Wasserwirtschaftskataster, Wien. ISBN 3-85 174-25-4: $248 \mathrm{pp}$.

Smol JP, and Störmer EF (Eds). 2010. The Diatoms. Applications for the Environmental and Earth Sciences. 2nd rev. ed. Cambridge University Press: 686 pp.

Spaulding SA, Lubinski DJ, and Potapova M. 2010. Diatoms of the United States. http://westerndiatoms. colorado. edu.

Thomas CD, Cameron A, Green RE, Bakkenes M, Beaumont LJ, Collingham YC, Erasmus BFN, Ferreira de Siqueira M, Grainger A, Hannah JH, Hughes L, Huntley B, van Jaarsveld AS, Midgley GF, Miles L, Ortega-Huerta MA, Peterson AT, Phillips OL, and Williams ES. 2004. Extinction risk from climate change. Nature 427: 145-148.

Uehlinger U, Robinson CT, Hieber M, and Zah R. 2010. The physico-chemical habitat template for periphyton in alpine glacial streams under a changing climate. Hydrobiologia, 657: 107-121. DOI 10.1007/s10750-009-9963-x.

Uehlinger U, Zah R, and Bürgi HR. 1998. The Val Roseg Project: Temporal and spatial patterns of benthic algae in an Alpine stream influenced by glacier runoff. In: K. Kovar, U. Tappeiner, N.E. Peters, and R.G. Vraig (Eds), Hydrology, Water Resources and Ecology in Headwaters. IAHS Press, Wallingford, U.K: 419-424.

USGS NAWQA Program. 2011. Current list of algae taxa found in NAWQA samples collected. Phycology Section, Patrick Center for Environmental Research, Academy of Natural Sciences, Philadelphia, PA. http://diatom.acnatsci. org/nawqa/ list.asp.

Van de Vijver B, Kerckvoorde AV, and Beyens L. 2003. Freshwater and terrestrial moss diatom assemblages of the Cambridge Bay area, Victoria Island (Nunavut, Canada). Nova Hedwigia 76(1-2): 225-243.

Vincent WF, and Howard-Williams C. 1989. Microbial communities in southern Victoria Land streams (Antarctica) II. The effects of low temperature. Hydrobiologia 172: 27-38.

Ward JV. 1994. Ecology of alpine streams. Freshwater Biol., 32: 277-294.

Yallop ML, and Anesio AM. 2010. Benthic diatom flora in supraglacial habitats: a generic-level comparison. Ann. Glaciol. 51(56): 15-22.

\section{APPENDIX}

Overall diatom species list (118 taxa) including relative abundances (\%) at sites 1-12 in SW-Canada; red list classification (RL) according to Lange-Bertalot, and Steindorf (1996) and trophic indication values (T) according to Rott et al. (1999); 1 - threatened with extinction; 2 - severly endangered 3 - endangered, G - probably endangered, R - rare, V - decreasing, * - at present not considered threatened, ** - surely not threatened, $\bullet$ - to be expected within the area, D - data scarce; uo - ultraoligotraphentic, o - oligotraphentic, om - oligomesotraphentic, $\mathrm{m}$ - mesotraphentic, me - mesoeutraphentic, e - eutraphentic, ep - eupolytraphentic, $\mathrm{p}$ - polytraphentic; taxa names acc. to ANSP-2011 taxonomic system, taxa names marked with an asterisk are taken from Hofmann et al. (2011).

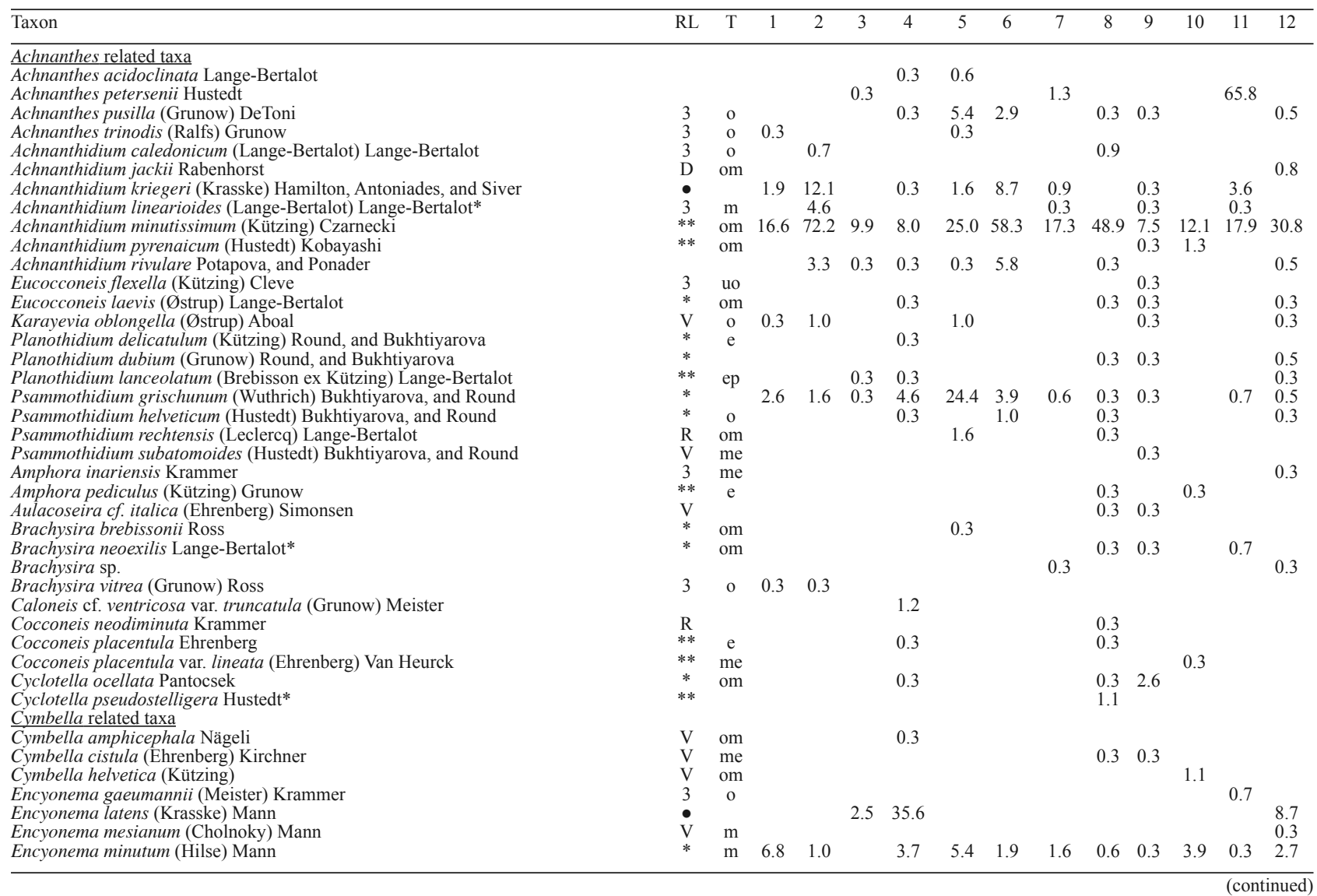




\begin{tabular}{|c|c|c|c|c|c|c|c|c|c|c|c|c|c|c|}
\hline Taxon & RL & $\mathrm{T}$ & 1 & 2 & 3 & 4 & 5 & 6 & 7 & 8 & 9 & 10 & 11 & 12 \\
\hline Encyonema neogracile Krammer & 3 & o & & & & & 11.2 & 1.0 & & & & & & \\
\hline Encyonema silesiacum (Bleisch) Mann & $*$ & $\mathrm{~m}$ & 0.6 & & 0.3 & 3.4 & & & 11.0 & 0.3 & 0.3 & 9.2 & & 8.2 \\
\hline Encyonopsis cesatii (Rabenhorst) Krammer & $*$ & o & & & & & & & & 0.3 & 0.3 & & 1.6 & 0.3 \\
\hline Encyonopsis microcephala (Grunow) Krammer & * & om & & & & & & & 0.3 & & & & & \\
\hline Reimeria sinuata (Gregory) Kociolek, and Stoermer & $* *$ & me & & & 0.3 & 0.3 & & & 0.3 & & & 2.9 & & 0.8 \\
\hline Diatoma anceps (Ehrenberg) Kirchner & $*$ & uo & & & & & & & 0.3 & & 0.3 & & & 0.3 \\
\hline Diatoma ehrenbergii Kützing & $* *$ & $\mathrm{~m}$ & & & & & & & & & & 42.4 & & \\
\hline Diatoma mesodon (Ehrenberg) Kützing & $*$ & o & & & 0.6 & 2.2 & & 1.9 & 6.0 & 0.3 & 0.3 & & & 0.5 \\
\hline Diatoma vulgaris Bory & $\mathrm{D}$ & $\mathrm{m}$ & & & & & & & & & & 5.5 & & \\
\hline Didymosphenia geminata (Lyngbye) Schmidt & 1 & o & & & & & & & & 0.3 & & & & \\
\hline Diploneis ovalis (Hilse) Cleve & V & o & & & & & & & & & & & & 0.3 \\
\hline Diploneis sp. & & & & & & & 0.3 & & & & 0.3 & & & \\
\hline Eunotia bilunaris (Ehrenberg) Souza & $* *$ & o & & & & 0.3 & 0.3 & & & & 0.3 & & & \\
\hline Eunotia cf. paludosa Grunow & $\mathrm{V}$ & & 0.6 & 0.3 & 0.3 & & 2.6 & 1.9 & & & 0.3 & & & 0.3 \\
\hline Eunotia exigua (Brébisson) Rabenhorst & $* *$ & uo & & 0.3 & & 0.3 & & & & & & & & \\
\hline Eunotia implicata Nörpel, Alles, and Lange-Bertalot & $\mathrm{G}$ & o & & & & 0.3 & & & & 0.3 & & & & \\
\hline Eunotia incisa Smith ex Gregory & $*$ & o & & & & & & & & & & & 1.6 & \\
\hline Eunotia minor (Kützing) Grunow & $*$ & $\mathrm{e}$ & & & & & & & & & 0.3 & & & \\
\hline Eunotia muscicola Krasske & - & & & & & & & & & & & & 0.3 & \\
\hline \multicolumn{15}{|l|}{ Fragilaria related taxa } \\
\hline Fragilaria capucina Desmazieres & $* *$ & $\mathrm{~m}$ & & & & 0.3 & 0.3 & 1.0 & 0.6 & & & & & \\
\hline Fragilaria tenera (Smith) Lange-Bertalot & $\mathrm{V}$ & o & 0.3 & 0.3 & & & & 1.9 & & 0.3 & 0.3 & 0.3 & & 1.6 \\
\hline Fragilaria vaucheriae (Kützing) Petersen & $* *$ & $\mathrm{~m}$ & & & 0.6 & & & & 0.3 & 8.2 & 1.4 & 4.2 & & 6.5 \\
\hline Hannaea arcus (Ehrenberg) Patrick & $* *$ & o & 55.5 & 0.7 & 81.1 & 6.2 & 4.8 & 6.8 & 41.8 & 27.8 & 0.6 & 2.1 & 2.3 & 25.9 \\
\hline Pseudostaurosira brevistriata (Grunow) Williams, and Round & $* *$ & e & & & & & 0.3 & & & & & 0.3 & & \\
\hline Staurosirella pinnata - Group (Ehrenberg) Williams, and Round & $* *$ & me & & & & & & & & & & & & 0.3 \\
\hline Synedra rumpens Kützing & $*$ & o & 0.3 & & & 0.3 & & & 0.6 & 2.0 & & & 0.7 & \\
\hline Ulnaria ulna (Nitzsch) P. Compére & $*$ & ep & & & & & & & & & 0.3 & & & \\
\hline Frustulia rhomboides (Ehrenberg) De Toni* & & uo & 0.3 & & & & & & & & 0.3 & & 2.0 & \\
\hline Gomphonema acuminatum Ehrenberg & $* *$ & me & & & & & & & & 0.3 & 0.3 & & & \\
\hline Gomphonema affine Kützing & $\mathrm{R}$ & $\mathrm{m}$ & & & & 0.3 & & & & & & 0.3 & & \\
\hline Gomphonema angustatum (Kützing) Rabenhorst & $*$ & o & & & & & 1.6 & & 0.3 & & 0.3 & & 0.3 & 0.3 \\
\hline Gomphonema cf. bipunctatum Krasske* & $\mathrm{R}$ & & & & & & 1.0 & & & & & & & \\
\hline Gomphonema cf. instabilis Hohn et Hellermann* & & & & & 0.3 & 0.3 & & & & & & & & \\
\hline Gomphonema micropus Kützing & $*$ & $\mathrm{~m}$ & & & 0.3 & 0.3 & 0.3 & & 0.3 & 0.3 & 0.3 & & & 0.3 \\
\hline Gomphonema olivaceum (Lyngbye) Kützing & $* *$ & $\mathrm{e}$ & & & & & & & & & & 4.2 & & 0.3 \\
\hline Gomphonema calcifugum Lange-Bertalot et Reichardt* & $*$ & om & & & 0.3 & 25.4 & 2.6 & & 0.3 & 1.4 & 0.3 & & & 1.9 \\
\hline Gomphonema parvulum (Kützing) Kützing & & e & 0.3 & & & & & & & & & & & 0.5 \\
\hline Meridion circulare (Greville) Agardh & $* *$ & me & 12.0 & & 0.3 & 0.3 & 0.3 & & 0.3 & 0.3 & 0.3 & & & 0.3 \\
\hline \multirow{2}{*}{\multicolumn{15}{|c|}{ Navicula related taxa }} \\
\hline & & & & & & & & & & & & & & \\
\hline Cavinula pseudoscutiformis (Hustedt) Mann, and Stickle & 3 & om & & & & & & & & & 0.3 & & & \\
\hline Diadesmis perpusilla (Grunow) Mann & $* *$ & om & & & 0.3 & 0.3 & 0.3 & & & & & & & \\
\hline Luticola mutica (Kützing) Mann & $* *$ & $\mathrm{e}$ & & & 0.3 & 0.3 & 0.3 & & & & & & & \\
\hline Luticola ventricosa (Kützing) D.G. Mann & $\mathrm{D}$ & ep & & & & & & 1.0 & & & & & & \\
\hline Mayamaea atomus (Kützing) Lange-Bertalot & $* *$ & $\mathrm{p}$ & & & & 0.3 & & & & 0.3 & 0.3 & & & \\
\hline Navicula cari Ehrenberg & $* *$ & $\mathrm{e}$ & & & & & & & & & & 0.3 & & \\
\hline Navicula cf. concentrica Carter et Bailey-Watts & 2 & & & & 0.3 & & & & & & & & & \\
\hline Navicula cf. cryptocephala Kützing & $* *$ & ep & & 0.3 & & & & & & & & & & \\
\hline Navicula cryptotenella Lange-Bertalot & & me & & & & & & & 0.3 & 0.3 & 0.3 & & 0.3 & 0.3 \\
\hline Navicula elginensis (Gregory) Ralfs* & $*$ & me & & & & & & & & & 0.3 & & & \\
\hline Navicula lanceolata (Agardh) Kützing & $* *$ & ep & & & & & & & & & & 0.3 & & \\
\hline Navicula radiosa Kützing & $* *$ & o & & & & & & & & & 0.3 & 1.8 & & \\
\hline Navicula rhynchocephala Kützing & $* *$ & me & & & & & & & & & 0.3 & & & \\
\hline Navicula $\mathrm{sp}$. & & & & & & & & 1.0 & & & 0.3 & & & \\
\hline Neidium ampliatum (Ehrenberg) Krammer & $\mathrm{V}$ & om & & & & & & & & & 0.3 & & & \\
\hline Neidium bisulcatum (Lagerstedt) Cleve & 3 & o & & & & & 1.3 & & & & & & & \\
\hline Nitzschia angustata (Smith) Grunow & $*$ & $\mathrm{~m}$ & & & & & & & & 0.3 & 0.3 & & & \\
\hline Nitzschia bryophila (Hustedt) Hustedt & $\mathrm{G}$ & & & & & & & & & & 0.3 & & & 0.3 \\
\hline Nitzschia cf. perminuta (Grunow) Peragallo & $*$ & me & 0.6 & & 0.3 & 0.3 & 1.9 & & 0.6 & 0.3 & 0.3 & & & 0.3 \\
\hline Nitzschia dissipata (Kützing) Grunow & $* *$ & me & & & & & & & 1.9 & 0.3 & 0.3 & 2.4 & & 0.3 \\
\hline Nitzschia fonticola (Grunow) Grunow & $* *$ & $\mathrm{~m}$ & & & & & & & & & & 4.7 & & 0.5 \\
\hline Nitzschia gracilis Hantzsch & $*$ & me & & & & & & & & 0.3 & & 0.3 & & \\
\hline Nitzschia pura Hustedt & $*$ & $\mathrm{~m}$ & & & & 0.3 & & & 0.6 & & & & & 0.3 \\
\hline Nitzschia recta Hantzsch ex Rabenhorst & $* *$ & e & & & & & & & & 0.3 & & & & \\
\hline Nitzschia sublinearis Hustedt & $*$ & $\mathrm{e}$ & & & & & & & 0.3 & & & & & 0.3 \\
\hline Pinnularia biceps Gregory & & & & & & & & & & & 0.3 & & & \\
\hline Pinnularia borealis Ehrenberg & & $\mathrm{m}$ & & & & & & 1.0 & 0.3 & & & & & \\
\hline Pinnularia cf. appendiculata (Agardh) Cleve & $*$ & $\mathrm{~m}$ & & & & & & & 0.3 & & & & & 0.3 \\
\hline Pinnularia cf. julma Krammer, and Metzeltin* & & & & & & & & & & & 0.3 & & & \\
\hline Pinnularia cf. rupestris Hantzsch & G & o & & & & 0.3 & & & & & & & & \\
\hline Pinnularia hilseana Janisch & & & & & 0.3 & & & & & & & & & 0.3 \\
\hline Pinnularia microstauron (Ehrenberg) Cleve & $\mathrm{V}$ & o & & & & & 0.3 & & & & & & & \\
\hline Pinnularia subcapitata Gregory & $*$ & o & & & & 0.3 & 1.3 & & & & & & & \\
\hline Stauroneis cf. alpina Hustedt & $\mathrm{R}$ & & & & & & 1.6 & & & & & & & 0.3 \\
\hline Stauroneis cf. prominula (Grunow) Hustedt & $\mathrm{R}$ & & & 0.3 & & & 0.3 & & & & & & & \\
\hline Surirella angusta Kützing & $*$ & $\mathrm{p}$ & & & 0.3 & 0.3 & 0.6 & & & & & & & 0.3 \\
\hline Tabellaria fenestrata (Lyngbye) Kützing & $\mathrm{V}$ & om & & & & & & & & 0.3 & 1.4 & & & \\
\hline Tabellaria flocculosa (Roth) Kützing & $* *$ & o & 0.3 & 1.0 & 0.3 & 0.6 & 0.3 & & 10.4 & 0.3 & 73.7 & & 1.0 & 1.1 \\
\hline
\end{tabular}

